Religare, ISSN: 19826605, v.16, n.2, dezembro de 2019, p.714-734

\title{
A representação do mito de Perséfone mencionado na Teogonia Hesiódica e descrito no hino Homérico a Deméter na Ática Arcaica
}

The representation of the perspective myth mentioned in the hydrogenic theogony and described in the hominian hym a Demeter in Arcaic Attic

Lion Granier Alves ${ }^{1}$ Sergio Rodrigues de Souza ${ }^{2}$

\section{Resumo}

O presente artigo aborda a questão da representação do mito de perséfone mencionado na teogonia hesiódica e descrito no hino homérico a Deméter na Ática arcaica. Sua relevância científica encontra-se no fato de explorar um formato de pensamento que possibilitou o nascimento da lógica abstrata. Sua relevância social está em esclarecer ao público sobre os vários formatos que a história tomou desde eras arcaicas até os dias atuais, passando da tradição oral à tradição escrita. Busca-se evidenciar a importância da representação do mito de Perséfone para a compreensão dos fenômenos da natureza na Ática Arcaica (VIIIVI a.C). Nas perspectivas da História Antiga, em conjunto com a Filosofia da Religião, foi realizado um movimento parcial de análise dos conceitos de mito e sagrado, tendo como proposta uma maior clareza do religioso-mitológico na forma de deuses. Buscou-se, nesse aspecto, reportar-se à literatura da Teogonia hesiódica e aos escritos de autoria anônima Hino Homérico a Deméter. Apresentouse uma hermenêutica introdutória dos textos, servindo de base para aprofundamentos futuros dos estudos de antiguidade, a partir de uma abordagem historiográfica centrada na dimensão de pertinência histórica.

Palavras-chave: Perséfone; Mito; Hino Homérico a Deméter; Fenômenos Naturais.

\footnotetext{
${ }^{1}$ Bacharel em Teologia pela Faculdade Unida de Vitória (UNIDA). Licenciado em História pela Universidade Estácio de Sá (UNESA). Licenciado em Filosofia pelo Centro Universitário Claretiano (CEUCLAR).

2 Professor licenciado em Filosofia e Sociologia. Doutor em Ciências Pedagógicas pela Universidad de Ciencias Pedagógicas “Enrique José Varona”. La Habana (Cuba). Pós-Doutor em Psicologia Social.
} 
Religare, ISSN: 19826605, v.16, n.2, dezembro de 2019, p.714-734

\section{Abstract}

This article deals with the question of the representation of the myth of the persephone mentioned in the theorhonic theogony and described in the homeric hymn to Demeter in archaic Attica. Its scientific relevance lies in the fact of exploring a thought format that enabled the birth of abstract logic. Its social relevance is to enlighten the public about the various formats that history has taken from archaic eras to the present day, from oral tradition to written tradition. It is tried to evidence the importance of the representation of the myth of Perséfone for the understanding of the phenomena of the nature in the Archaic Ática (VIII-VI a.C). In the perspectives of Ancient History, together with the Philosophy of Religion, a partial movement of analysis of the concepts of myth and sacred was realized, having as proposal a greater clarity of the religiousmythological in the form of gods. In this regard, we sought to refer to the literature of the Hesiodic Theogony and to the writings of anonymous authors Homeric Hymn to Demeter. An introductory hermeneutics of the texts was presented, serving as the basis for future studies of ancient studies, based on a historiographical approach centered on the dimension of historical relevance.

Keywords: Persephone; Myth; Homeric hymn to Demeter; Natural Phenomena.

\section{Introdução}

Este artigo apresenta alguns conceitos de mito, sagrado e religião, abordando também, a relevância que possuía o espaço geográfico e sóciocosmológico no universo grego. Além disso, menciona o lugar que têm algumas narrativas e ritos, na cultura dos povos antigos, na qualidade de elementos da manifestação de sua religiosidade. Com uma abordagem historiográfica, em conjunto com a Filosofia da Religião, reporta-se também à literatura da teogonia hesiódica e dos escritos de autoria anônima denominados de Hino Homérico a Deméter.

Em um segundo momento, apresentar-se-á a natureza e o sentido de Deméter, com base em vestígios históricos da deusa entre os povos pré-helênicos, inserindo-a no panteão grego. A partir desses vestígios, será verificado o sagrado, com base na análise da sua linhagem genealógica e de inúmeros nomes que lhe 
Religare, ISSN: 19826605, v.16, n.2, dezembro de 2019, p.714-734

são atribuídos. Será realizada uma tentativa de compreender os fenômenos da natureza a partir do mito, a saber: o de Deméter e Perséfone.

Toda a construção poética envolvendo o mito tem a intenção de explicar um fenômeno natural, para o qual não existia, ainda, uma explicação lógica. Há que esclarecer um fato, o mito não representa a poesia, ele é uma narrativa, um conto maravilhoso, por si só e a perícia do aedo fez com que se tornasse encantador. Esta conjuntura é o que chegou até nós, por meio dos estudiosos da literatura, mas em seu respectivo tempo sociológico, esta construção fantástica representava uma guerra santa, uma forma de mostrar, logicamente, que aquele Deus particular merecia um lugar de destaque entre os deuses e deveria receber honrarias, libações, orações, portanto, representava um ser que detinha poder até sobre o invisível. Tratava-se de um brilhante jogo político na disputa pelo poder.

\section{O mito e a religião na Grécia Antiga}

A compreensão dos mitos gregos ocorre por meio da forma escrita e das imóveis composições da arte alegórica, sendo habitual na mitologia antiga. A estilística da escrita altera certas particularidades imprescindíveis. A título de exemplo, seria sua diversidade, sendo uma matriz fundamental na mitologia. A ausência do sincretismo e do simbólico nas interpretações tornaria o mito fixo em um caráter apenas descritivo. Conforme foi citado, o mito mantém suas versatilidades; ora, em obra de arte, ora em poemas e hinos de conteúdo mitológico.

Ocorre que um conto mitológico não foi feito para ser lido, mas para ser ouvido, daí seu sentido etimológico e semântico conto. Se tivessem sido pensados, em sua trajetória arcaica, para serem escritos, assim seriam chamados. O sentido não era que o ouvinte refletisse sobre o seu sentido léxico e epistemológico, mas, sim sobre o seu efeito psicológico sobre a conduta ética (comportamental) dos ouvintes, porque eles não realçavam, em sua interpretação primitiva, a beleza 
Religare, ISSN: 19826605, v.16, n.2, dezembro de 2019, p.714-734

dos fenômenos naturais e nem o ciclo da vida; mostravam a ira divina, sentimento este que deveria, de alguma forma, ser aplacado. Portanto, a intenção era despertar o patético no ouvinte, o terror, o medo do sobrenatural, representado na persona do Deus em questão.

No que concerne à redução do mito a uma obra escrita, há um efeito negativo de grande importância e influência na representação e compreensão do sentido original que estava impregnado nos contos (VERNANT, 1973), pois a canonização ou a inflexibilidade da narrativa mitológica produz uma rigidez à interpretação alegórica. Vale destacar que esta análise é contemporânea e que nos tempos áureos da representação tragicômica ateniense, os poetas trágicos eram detentores de toda a liberdade poética para alterarem os mitos em sua forma original para adequá-los às suas respectivas peças, sem perdas de sentido figurativo para os fins a que se destinavam. Mesmo Sêneca (Século I d.C.) e Racine (Século XVIII) fizeram mudanças significativas nos respectivos contos de Hipólito e Fedra, sem que isto custasse-lhes críticas desfavoráveis, do ponto de vista ético. Do ponto de vista literário, quando comparado com a obra original de Eurípides, houve duras críticas dirigidas aos escritores latinos. Em caso de fidedignidade sobre a qual a forma escrita represente uma singularidade das mitologias antigas, faz-se importante salientar que "a mitologia grega ainda está comprometida por outras particularidades. Os mitos existem e, fora do mundo grego, mesmo em sua rígida forma escrita, conservaram um nítido e indiscutível caráter religioso" (BRANDÃO, 2004, p. 25).

Esta característica peculiar da mitologia grega é devido ao fato de que, quando a religião começa a dominar a Grécia, com o surgimento do Arconte-Rei, estes sacerdotes passaram a recontar os mitos, incorporando seus deuses particulares e familiares nestas aventuras. $\mathrm{O}$ mito primitivo foi utilizado como base para a elaboração de outros mais bem arrojados nos campos linguísticos, conferindo-lhes uma beleza e um encanto singulares, até mesmo porque eram 
Religare, ISSN: 19826605, v.16, n.2, dezembro de 2019, p.714-734

utilizados para demonstrar todo o poder daquele Deus, bem como sua fúria vingativa ou estado de benevolência para quem obedecesse aos seus princípios e assim atrair adeptos.

A mitologia é apresentada para pesquisadores e admiradores por meio da poesia, da arte figurativa e da literatura erudita, isto é, em vestígios históricos de caráter profano. O termo profano supracitado deve ser interpretado de forma ampla, visto que poesia, arte figurativa e literatura erudita sustentaram sua legitimação no mito. $\mathrm{O}$ conteúdo mitológico produzido por poetas e artistas na Grécia Arcaica não é apenas submetido exclusivamente aos critérios religiosos, mesmo considerando que a literatura, arte figurativa e religião estão coadunadas. Cada produção artística e literária conserva em si requisitos próprios, "entre narrar um mito, que é uma práxis sagrada, em determinadas circunstâncias, para determinada pessoa, e compor uma obra de arte, mesmo alicerçada no mito vai uma distância muito grande" (BRANDÃO, 2004, p. 26).

É imprescindível esclarecer que o conceito de mito neste artigo não será associado à ideia de uma conotação - que entendemos por fábula, lenda, invenção e ficção -, mas, atribuído o termo a uma concepção cujas sociedades antigas atribuíam. De acordo com Mircea Eliade (1989a), o mito é a narrativa de fatos que sucederam no tempo primordial, mediante a intervenção de deuses. Assim, "toda manifestação do sagrado é consequente: todo rito, todo mito, toda crença ou figura divina reflete a experiência do sagrado e, por conseguinte, implica as noções de serem, significação e verdade" (Id., p. 60).

Todavia, o mito será constantemente uma representação coletiva emitida de múltiplas gerações, no qual transmite por meio da experiência com o sagrado uma interpretação do mundo. "Mito é, por conseguinte, a parole, a palavra 'revelada', o dito" (ELIADE, 1989a, p.60). Ele expressa a condição da linguagem, representando um discurso que circunscreve e consolida um fenômeno. Leenhardt corrobora com Brandão ao interpretar o mito como uma espécie de 
Religare, ISSN: 19826605, v.16, n.2, dezembro de 2019, p.714-734

revelação destinada a circunscrever e fixar um acontecimento. De acordo com o autor, "o mito é sentido e vivido antes de ser inteligido e formulado. Mito é a palavra, a imagem, o gesto que circunscreve o acontecimento no coração do homem, emotivo como uma criança, antes de fixar-se como narrativa" (DER LEEUW, 1940, p. 131).

O sagrado é autêntico. O mesmo se compõe na compreensão de um mundo trans-humano, habitualmente de origem divina, transcendendo o mundo de vigília, sobrepujando a representação da realidade instantaneamente visível e sensível; o sagrado surge em objeção ao profano, manifestando-se no mundo por meio de sinais e elementos. A revelação do sagrado sobrevém quando algo que supera o real se dá a conhecer ao homem, consistindo em uma ordem diferente do dia a dia, como elemento aditivo ao real. A este tipo de experiência atribui-se o termo hierofania, vocábulo composto por duas expressões gregas: hierós (santo, sagrado) e fanein (manifestar). Prontamente, compreende-se como hierofania toda e qualquer manifestação do sagrado. Acerca da hierofania, Mircea Eliade preceitua:

O homem toma conhecimento do sagrado porque este se manifesta, se mostra como algo absolutamente diferente do profano. A fim de indicarmos o ato da manifestação do sagrado, propusemos o termo hierofania. Este termo é cômodo, pois não implica nenhuma precisão suplementar: exprime apenas o que está implicado no seu conteúdo etimológico, a saber, que algo de sagrado se nos revela. Poder-se-ia dizer que a história das religiões - desde as mais primitivas ${ }^{3}$ às mais elaboradas - é constituída por um número considerável de hierofanias, pelas manifestações das realidades sagradas (ELIADE, 1992b, p. 12).

A hierofania vai além da instância das instituições jurídico-religiosas, encontrando-se primeiramente no contato do homem com a Natureza. Assim, 
Religare, ISSN: 19826605, v.16, n.2, dezembro de 2019, p.714-734

todas as esferas da vivência humana (tidas como socialmente reconhecidas como ambiente religioso) podem figurar como objetos da experiência do sagrado. Em O sagrado e o profano, Eliade se propõe a investigar as manifestações religiosas por meio das hierofanias, a saber, por meio da revelação e manifestação do sagrado nos mais diversos quadros sócio-históricos e culturais. O sagrado é caracterizado como instância supralunar auto-revelada no material. Dessa forma, ao se invocar um deus, o grego expressa sua devoção não ao deus em si, mas ao que ele desvela na qualidade de sagrado. Nesse sentido, de acordo com Eliade:

Nunca será demais insistir no paradoxo que constitui toda hierofania, até a mais elementar. Manifestando o sagrado, um objeto qualquer se torna outra e, contudo, continua a ser ele mesmo, porque continua a participar do meio cósmico envolvente. Uma pedra sagrada nem por isso é menos uma pedra; aparentemente (para sermos mais exatos, de um ponto de vista profano) nada a distingue de todas as demais pedras. Para aqueles a cujos olhos uma pedra se revela sagrada, sua realidade imediata transmuda-se numa realidade sobrenatural. Em outras palavras, para aqueles que têm uma experiência religiosa, toda a Natureza é suscetível de revelar-se como sacralidade cósmica. $\mathrm{O}$ Cosmos, na sua totalidade, pode tornar-se uma hierofania (ELIADE, 1992, p.13).

O conceito do homo religiosus, como o denomina Mircea Eliade, atrela-se especialmente às sociedades antigas, das quais os mitos, os rituais, os símbolos e os deuses faziam parte da vida cotidiana. Os mesmos davam um novo sentido à realidade a partir da releitura do real, proveniente das experiências com o sagrado. Para os gregos, o sagrado não se compõe de uma religiosidade distante e inventada, mas a própria constitui-se a partir de rituais e celebrações sendo uma grandeza ontológica primordial dos povos antigos.

Rudolf Otto interpreta o sagrado associando-o ao ético, moral, e à bondade. Assim sendo, o sagrado é coberto de uma limpidez moral e ética incomparável e inacessível, imputando ao ser que é sagrado uma pureza extraordinária. A proposta de Otto, na obra O Sagrado, é apresentar uma 
Religare, ISSN: 19826605, v.16, n.2, dezembro de 2019, p.714-734

concepção do sagrado, no qual o próprio não é indubitavelmente avaliado e entendido e esclarecido; o mesmo existe apenas no universo do inefável. "Para identificar o sagrado no seu aspecto não-racional ele faz uso da palavra numinoso ${ }^{4}$, aquilo que não pode ser entendido, porque não pode ser explicado; isso parece ser óbvio, e o é, já que seu caráter é de algo inefável - se não se pode dizer, não se pode entender (DA SILVA, 2005, p. 02).

Todavia, a inteligibilidade, que o autor lida com a temática supracitada, restringe a concepção do sagrado exclusivamente, às pessoas que experimentaram uma experiência com o sagrado. A partir dela é que compreenderam; no entanto, jamais manifestaram racionalmente, o que sentiram e viveram em relação ao sagrado, ao numinoso. $\mathrm{O}$ misterioso que surge dessa experiência com o sagrado converte-se espontaneamente em terrível, uma vez que o desconhecido oculta-se na incompreensibilidade, sendo o mesmo impenetrável. Pois tudo que é misterioso causa um profundo espanto. Todavia, esse espanto ou terror não é, segundo o autor, demoníaco, não sendo associado ao horror, não provoca nem desperta aversão.

Ele causa o espanto por que está ligado ao estranho e não ao sinistro, está ligado ao totalmente outro, ao mirum, que nos deixa estupefatos e nos paralisa. Na qualidade de totalmente outro, o mirumé primeiramente o incompreensível e inconcebível, o akatalêpton, como diz Crisóstomo, aquilo que foge ao nosso entendimento na medida em que "transcende [nossas] categorias" (OTTO, 2007, p. 56). Contrapondo a razão humana e confundindo-a, o mirum é paradoxal, encontrando-se acima da cognição humana, anulando-a e confundindo-a.

4 “O numinoso não pode ser entendido, porque não pode ser explicado, isso parece ser óbvio, e o é, já que seu caráter é de algo inefável - se não se pode dizer, não se pode entender. Porém a simplicidade, como Otto trabalha a questão, transforma-a em algo de reduzida compreensão, já que para ele, somente os que viveram uma experiência religiosa é que podem entender, mas não expressar, o que sentiram e viveram em relação ao sagrado, ao numinoso" (OTTO, 2007, p. 12). 
Religare, ISSN: 19826605, v.16, n.2, dezembro de 2019, p.714-734

A religião grega arcaica e clássica apresentada entre os séculos VIII e IV é dotada de características próprias. Diferente das religiões do antigo OrientePróximo e do Extremo-Oriente, a saber, Hebraica, hinduísmo e budismo prestavam cultos a vários deuses, mas, diferentemente destas, não conheceu profetas nem messias. No antigo Oriente-Próximo, uma das mais importantes religiões é a Hebraica. Seus profetas são classificados por teólogos e historiadores contemporâneos de menores e maiores. Os maiores são Isaías, Jeremias, Ezequiel e Daniel, e os menores Oséias, Joel, Amós, Obadias, Jonas, Miquéias, Naum, Habacuque, Sofonias e Ageu. No Extremo-Oriente, temos o budismo, que é representado por seu fundador e profeta Buda, tendo as principais escolas Zen, Terra Pura e o budismo tibetano, no Tibete, China e Japão, como seus respectivos representantes.

Outras características importantes são suas matrizes firmadas em uma tradição que engloba "tudo aquilo que dá à Grécia das cidades-estados sua fisionomia própria, desde a língua, a gestualidade, as maneiras de viver, de sentir, de pensar, até os sistemas de valores e as regras vida coletiva" (VERNANT, 2009, p. 14). A tradição citada acima não tem um víeis dogmático e institucional hierárquico. A religião grega não conheceu um livro sagrado no qual a verdade estava expressa a partir de palavras. Na Grécia, saberes tradicionais eram transmitidos por certas narrativas.

O poeta Hesíodo, pertencente à tradição oral, por volta do século VIII, em seu texto Teogonia, disserta sobre a criação do universo e relaciona sistematicamente cada uma das gerações divinas. No universo antropomórfico do panteão grego, difundiram-se divindades. Tendo lugar de destaque entre os deuses e deusas Zeus, Hera, Ártemis, Hermes, Afrodite, Athená e Apolo. Sendo eles associados geralmente a uma atividade específica - a título de exemplo, Afrodite - está coligada ao prazer sexual; Athená às habilidades técnicas; Hermes às fronteiras, estradas e outras associações pormenorizadas. 
Religare, ISSN: 19826605, v.16, n.2, dezembro de 2019, p.714-734

Outros personagens eram reverenciados, sendo eles fundamentais, porém de pouca expressão, a saber: Eilêtia, a deusa do parto, ou Bóreas, o vento do norte. Segundo Cartledge (2009, p. 442), “personificações como o desejo representado por Hímeros e Vitória evidenciado em Niké, também eram veneradas assim como os heróis que pareciam deuses porque eram poderosos, mas diferentes porque desfaleciam."

Os deuses gregos tinham atributos relacionados às forças da natureza, e, conforme supracitado, estava ligado aos homens possuindo desejos, ódio, amor e perambulavam pelo mundo estando em permanente contato com os humanos.

Ponderando, as divindades e heróis jamais se resumem a um sistema globalizado. "Suas composições e características variam de um lugar para o outro, mantendo o pluralismo de convicções, característica fundamental da sociedade grega" (CARTLEDGE, 2009, p. 442). A religião dos gregos faz parte da sua vida cotidiana, sendo inviável desassociá-la, tão imprescindível para as narrativas e memórias mitológicas que a hipótese de separá-la é plenamente sem coerência no enredo da Grécia Antiga.

Neste contexto, os humanos prestavam cultos e demonstravam respeito aos deuses por meio de ritos em festivais. Os atos sagrados faziam parte da matriz religiosa dos gregos e, a partir deles, adoravam as divindades. Os festivais ditavam a celeridade da vida dos helenos; os calendários eram múltiplos, sendo comuns os nomes dos meses (Heraios, de Hera; Hestiaios, de Héstia, a deusa do lar) e festivais (Thesmophorion, do festival de Deméter) derivarem das divindades.

Nas cerimônias sagradas, o intervalo era maior do que um ano-calendário. Por exemplo, "os atletas de todo o mundo grego treinavam para se encontrar a cada quatro anos para disputar honrarias no recinto de Zeus em Olímpia, durante os jogos Olímpicos" (CARTLEDGE, 2009, p. 444). A vida pública e privada era influenciada pelos rituais. No nascimento, por exemplo, o recémnascido era consagrado a Héstia. Havia, ainda, o ritual da lareira, no qual o 
Religare, ISSN: 19826605, v.16, n.2, dezembro de 2019, p.714-734

neonatal era carregado em volta da mesma em um ato cerimonial. O casamento e a morte eram marcados ritualmente, sendo momentos propícios para as práticas religiosas.

A vida do indivíduo grego era influenciada por muitos ritos que produziam experiências com o sagrado. Por exemplo, as Antestérias, festivais de primavera consagrados ao deus Dionísio solenizada em Atenas e cidades jônicas do mês de Antesterião. Consagravam também o retorno da primavera e o vinho novo que saboreavam no primeiro dia. Neste festival todos eram envolvidos, mas a festa tinha uma maior representatividade para as crianças e jovens, no exórdio do vinho novo, ato auxiliado por um ritual do qual a comunidade participava em conjunto ingerindo vinho. Também faziam parte do ato ritualístico as crianças de três anos; nela, elas recebiam pela primeira vez um cântaro.

A civilização helênica celebrava a maioria de seus festivais nos santuários, localizados nos centros das cidades (a Acrópole ateniense, o santuário de Apolo, em Corintos); em locais mais afastados dos centros populacionais (o santuário de Hera, perto de Argos) e em locais com grandes aglomerações populacionais, nos quais peregrinos de muitas localidades buscavam no santuário uma interação e comunhão com as divindades (Delfos, Olímpia).

O templo era a morada dos deuses e o altar de sacrifício tinha uma representação simbólica significativa para o indivíduo que ali oferecia a oferta. Os animais eram oferecidos de duas maneiras na Grécia antiga: um era conduzido aos deuses que moravam no Olimpo, o outro aos deuses que ocupavam as profundezas da terra, denominados de ctonianos e infernais. Uma vez que Hades não tinha templo, não eram oferecidos animais imolados em seu nome, sendo o único deus que não recebia nenhum tipo de sacrifício.

\section{O mito de Perséfone e sua descrição em Hesiodo e nos hinos Homéricos}


Religare, ISSN: 19826605, v.16, n.2, dezembro de 2019, p.714-734

O conjunto de Hinos Homéricos (estima-se que os Hinos foram escritos entre os séculos VII e VI a.C) consiste de trinta e três hinos em honra de múltiplos deuses gregos, sendo dois em reverência a Deméter. Os hinos mais extensos são O Hino Homérico à Deméter I, os hinos à Afrodite I, Apolo I e Hermes I. O restante, com exceção do Hino a Dioniso, que possui cinquenta e nove versos, são curtos, e sua extensão não se compara com os primeiros hinos já citados.

O Hino Homérico a Deméter permite uma interpretação que dá seguimento à ordenação do cosmo narrada na Teogonia de Hesíodo, e é a partir dessas duas fontes que se desenvolve a pesquisa Acerca do Hino Homérico à Deméter. I, N. J. Richardson escreve um comentário amplo com o título The Homeric Hymnto Demeter, que permite que pesquisadores tenham acesso a uma boa tradução dos textos literários. Para aprofundamento da introdução do culto de Mistérios em Elêusis na Grécia Antiga, o leitor pode consultar a obra do mitólogo romeno Micea Eliade, que faz uma abordagem profunda e com muita clareza didática.

A representação do mito de Deméter, juntamente com seu sentido e natureza, alcança significação a partir da compreensão das suas origens, que ocorre, segundo Brandão, na chegada dos primeiros indo-europeus, por volta século XIX a.C. ao território da futura Hélade. Há vestígios históricos de que nesse período a Grécia continental era povoada, ao longo de todo o território (Anatólia) por civilização agrícola, que prestava culto à Grande-Mãe, deusa dos animais, da fertilidade e fecundidade do solo. Esse povo possivelmente desapareceu após a primeira migração de invasores indo-europeus.

Os povos indo-europeus não construíram um império estruturado. As características desses povos eram o nomadismo pastoril, o arcabouço da família era patriarcal, o gosto pelas raízes e a estrutura militar designada às conquistas. Por volta do ano três mil, ocorreram contínuas migrações, que os subdividiram em diversos grupos linguísticos. Alguns seguiram em direção à Ásia, permanecendo outros na Europa. De acordo com Mircea Eliade (1978), esses 
Religare, ISSN: 19826605, v.16, n.2, dezembro de 2019, p.714-734

povos desenvolveram uma teologia e uma mitologia própria, deixando uma lacuna temporal entre as primeiras e as últimas migrações; a segunda invasão ocorreu no século XVI a.C. pelos Aqueus e Eólios.

Uma nova invasão ocorre, de acordo com o autor citado, por volta do século XII a.C, pelos Dórios, impossibilitando a identificação dos fundamentos comuns na teologia e na mitologia da datação histórica, "pois as longas e lentas migrações permitiram o contato com outras culturas promovendo alterações ao acervo religioso original" (MASSI, 2001, p. 54). Sem dúvida, os traços de um povo pastoril semelhante a dos indo-europeus, são incompatíveis com uma sociedade agrícola com que os primeiros conquistadores se depararam em território grego.

Alguns arqueólogos apresentam hipóteses de que a primeira migração desses invasores inseriu a religião patrilinear na Grécia, esclarecendo o sumiço quase que total dos núcleos urbanos, do culto da Grande-Mãe e das estatuetas no qual representavam deusas. Não sendo alcançada por invasões entre os séculos XX-XIV a.C., a ilha de Creta se desenvolvia. O resultado desse florescimento foi o desenvolvimento cultural político, econômico, religioso e social do povo cretense, por meio da gestão de Cnossos.

De acordo com Mossé (1989), esse período histórico é conhecido como um período obscuro, e os poemas homéricos estão vinculados a esse momento da civilização Minóica ${ }^{5}$ Segundo o autor, o desaparecimento da escrita e a diminuição dos registros materiais e artísticos fizeram com que o recorte temporal fosse atrelado a um período conturbado. Devido à dificuldade de pesquisar sobre a datação supracitada, o que conhecemos desse período chegou até nós, principalmente por meio de poesias, transmitido oralmente pelos Aedos (MORRIS, 2001). Tornando-se uma civilização próspera e com enorme poder bélico, os Micênicos controlavam a região. Os esclarecimentos de Moses Finley

\footnotetext{
${ }^{5}$ A civilização micênica desenvolveu-se durante o período que se convencionou chamar de Idade do Bronze, aproximadamente entre 1600 e 1200 a.C.
} 
Religare, ISSN: 19826605, v.16, n.2, dezembro de 2019, p.714-734

(1990) possibilita a compreensão de que o crescimento e sua expansão são um mistério para historiadores e arqueólogos. De acordo com Page (1965), as construções de hipóteses e especulações suscitadas sobre a origem dessa civilização são um tanto românticas.

A magnitude da representatividade da Grande-Mãe era visível em diversas culturas, "mas o que permaneceu inalterado foi que todas eram a mãe dos deuses, dos homens e de tudo quanto existe e a fecundidade era um traço comum que as unia ao velho tema minóico" (MASSI, 2001, p. 54). A religião minóica exerceu influência sobre a religião grega não só na inserção de deuses na religião dos helenos (Réia, Hera e Perséfone), mas também nos mitos e no culto a Deméter. A Deusa-Mãe era a divindade da fertilidade, das montanhas, das florestas e dos animais. Apesar da poucas fontes a respeito da Deusa-Mãe, ela se fazia presente na civilização Minóica, sendo específicos os cretenses, compreendendo-se que a sua religião encontrava-se centrada no feminino, em que a grande-mãe Réia, deusa de todo o Olimpo, era cultuada.

O sincretismo religioso compõe a religião e a diversidade de deuses gregos, a saber, que a patrilinhagem (panteão masculino) presente nesta mesma pluralidade sofreu uma grande influência da religião indo-européia, tendo Zeus Olímpico como o soberano dos homens e dos deuses ${ }^{6}$. A matrilinhagem (panteão feminino) constitui a multiplicidade grega por meio da Terra-Mãe, que tem um caráter ctônico e agrícola, sendo a genitora dos homens, deuses e de tudo o que existe. De acordo com Massi (2001, p. 55):

Esse sincretismo, aliado a outras influências religiosas, especialmente egípcias, enriqueceram o patrimônio grego, fazendo com que as divindades helênicas tivessem um caráter composto, miscigenado e heterogêneo, o que explica a multiplicidade de funções e um entrelaçamento de mitos em relação a uma mesma divindade. Um exemplo disso é o próprio

${ }^{6}$ Cf. HESÍODO. Teogonia. São Paulo: Iluminuras, 2012. V. 477-480. 
Religare, ISSN: 19826605, v.16, n.2, dezembro de 2019, p.714-734

Zeus, que apesar de ser um deus indo-europeu, nasceu em Creta, onde tem seus primeiros ritos iniciáticos.

Neste contexto, de caráter composto, miscigenado e heterogêneo, ocorre na Grécia Antiga à iniciação ao culto a Deméter. Originada em Creta, é muito provável que sacerdotes da deusa Réia importaram sua representação simbólicosagrada. Conhecida como deusa mãe, filha de Cronos e Réia, deusa da terra cultivada, das colheitas e das estações do ano, a deusa era responsável pela reprodução da vida, principalmente da vida vegetal, consequentemente esta condição estende-se à vida animal e humana, porque permite a composição do ciclo biológico, dependentes que todos estes seres são da natureza e de seus benefícios.

No Hino Homérico à Deméter I, o autor narra o mito de Deméter e Perséfone (Koré) e como sucedeu seu sequestro, sendo o ator principal desse enredo o deus do mundo inferior, Hades. A separação das deusas foi traumático. A narrativa é anteriormente mencionada por Hesíodo em sua Teogonias. Perséfone, assim como Deméter, é originária de Creta. A mesma é representada como deusa das ervas, flores, frutos e perfumes. A deusa é filha de Zeus e Deméter, e, por diversas vezes, as duas divindades foram invocadas como Duas Deusas e atribuíam o nome a elas de "Deméteres" (BURKERT, 1993, p. 314).

Havia a crença de que fazendo adorações à filha, esta poderia intervir junto à mãe, para promover as bênçãos necessárias aos suplicantes. E acrescentase o fato de que por ser adorada em várias localidades diferentes, muitas delas sem comunicação umas com as outras, foi-se criando vários epítetos a um mesmo deus ou deusa. Este, um dos motivos porque, Perséfone é conhecida por muitos epítetos, a saber: Epaine, Praxidikê, Sôteira, MegalaThea, Ctonica, e Karpophoros. De acordo Junito de Souza Brandão: A dupla formada por Deméter e Core é uma junção muito frequente em Creta, de uma deusa mãe e de uma jovem (Core significa jovem) filha. O rapto de Core por Plutão, rei do Hades, e a 
Religare, ISSN: 19826605, v.16, n.2, dezembro de 2019, p.714-734

busca da filha pela mãe relembram as cenas de rapto muito frequentes no culto cretense da vegetação. "A junção, todavia, de Core, a semente de trigo lançada no seio da Mãe-Terra, Deméter, com a lúgubre Perséfone, rainha do Hades, é deveras estranha, mas ambas, mercê do sincretismo, constituem a mesma pessoa divina" (BRANDÃO, 2004, p. 73).

A mitologia foi sendo adaptada pelos sacerdotes e pelos poetas, à medida que histórias dos suplicantes foram sendo recolhidas, a fim de explicar o comportamento do clima. Era um tempo em que a explicação dos fenômenos climáticos se dava por meio do mythos e não do logos. Os aedos e os rapsodos conferiram uma belíssima aura poética a estas situações, formando os contos maravilhosos que chegaram até os dias atuais e, se alguma variação ocorreu isto se deve à influência latina.

\subsection{O rapto de Perséfone mencionado na Teogonia Hesiódica e sua descrição no Hino Homérico a Deméter}

O poeta Hesíodo nasceu na povoação de Ascre, que tem sua localidade em Beócia (Ásia menor) nos fins do século VIII a.C. Filho de pai pobre originário de Cime, na Eólida, o camponês teve uma vida árdua e difícil, e, como agravante, com a morte do seu pai, no ato da divisão da herança paterna, entrou em um embate com seu irmão Perses, que subornou treze juízes, fazendo com que Hesíodo perdesse parte da sua herança. Em seu poema Trabalhos e Dias lê-se sobre o seu pai, quando narra também a disputa por herança no qual foi ludibriado por seu irmão.

Faz-se necessário, neste primeiro momento, apresentarmos a Teogonia. Em seu texto, o poeta expõe a genealogia dos deuses de forma organizada e metódica, de acordo com Finley, constam na Teogonia mais de 350 deuses, semideuses, heróis e personagens. O poema de cunho didático de Hesíodo apresenta a 
Religare, ISSN: 19826605, v.16, n.2, dezembro de 2019, p.714-734

genealogia dos imortais, consolida a ideia da origem do universo com base na cosmogonia, que pode ser entendida como a origem do mundo.

O primeiro estágio da Teogonia, de acordo com Brandão (2004), pode ser estruturado da seguinte forma: Invocação às Musa (cf. Teog. vv1-115) podemos desmembrar a narrativa em dois segmentos: uma narrativa (Id., vv 1-34) e um hino (Id., vv 35-115). Em um segundo momento Hesíodo disserta sobre o Nascimento do Universo (Id., vv 116-132). Conforme o classicista “o estágio primordial (era panteística), no princípio era o Caos (vazio primordial, vale profundo, espaço incomensurável), matéria eterna, informe, rudimentar, mas dotada de energia prolífica" (BRANDÃO, 2004, p. 154), e por um processo de emanação veio Geia (Terra), Tártaro (personificação do mundo inferior) e Eros (Amor). Assim, vê-se em Teogonia a seguinte passagem:

Sim bem primeiro nasceu Caos, depois também Terra de amplo seio, de toda a sede irresvalável sempre, dos imortais que têm a cabeça do Olimpo nevado, e Tártaro nevoento no fundo do chão de amplas vias, e Eros: o mais belo entre Deuses imortais, soltamembros, dos Deuses todos e dos homens todos ele doma no peito o espírito e a prudente vontade. Do Caos Érebos e Noite negra nasceram. Da Noite, aliás, Éter e Dia nasceram, gerou-os fecundada unida a Érebos em amor. Terra primeiro pariu igual a si mesma Céu constelado, para cercá-la toda ao redor e ser aos Deuses venturosos sede irresvalável sempre. Pariu altas Montanhas, belos abrigos das Deusas (HESÍODO, 2012, s.p.; cf. Teog. vv 116-126).

A Teogonia não descreve a procura de Deméter por Perséfone, após a deusa descobrir o sequestro da sua filha o fato é narrado no Hino Homérico. Apesar de ser concedida a autoria a Homero, não cabe ao poeta a composição dos hinos. O termo homérico lhe é atribuído devido às impressões da escrita épica nos poemas, a saber, o metro épico (hexâmetro dactílico), a narrativa direta e a apresentação de uma relação entre oralidade e escrita.

Conforme o Ordep Serra (2009), as proximidades e impressões da escrita nos Hinos Homéricos não se assemelham apenas a Homero. As fórmulas e 
Religare, ISSN: 19826605, v.16, n.2, dezembro de 2019, p.714-734

esquema da poesia hesiódica deixaram suas marcas, uma vez que ambas dedicam-se a narrativas descritivas. Os hinos foram escritos o século VII a.C. e início do VI a.C., sendo compostos com o volume de quatrocentos e noventa e cinco versos para narrar o mito do rapto de Perséfone.

Apresenta-se, a seguir, um resumo da narrativa mítica do rapto de Perséfone, descrita no Hino Homérico a Deméter. Inicia-se com Perséfone e Zeus colhendo flores ( $c f . v v$ 1-25). Repentinamente, abre-se uma fenda no solo próximo a deusa; dela emerge Hades, o senhor do mundo dos mortos. Ele, com sua astúcia, rapta Perséfone. Perséfone gritou, mas não foi socorrida. Vejamos: “Ela, então, gritou alto com a voz chamando o Cronida, o pai supremo e melhor. Nenhum dos imortais e nenhum dos homens mortais ouviram a voz [...]". (Id., vv. 46-47)

Sua mãe Deméter, angustiada com o sumiço da sua filha, entrou em um estado de tristeza profunda e durante nove dias vagou pela terra procurando sua filha (Id., vv. 46-47). No décimo dia, deparou-se com a deusa Hécate (Id., vv. 5258). Indagando-a sobre Perséfone e Hécate, confirmou ter escutado seus gritos, porém, não viu o rosto de quem a havia sequestrado. Deméter e Hécate dirigiram-se ao deus que vigia homens e deuses, Hélios, este disse que Hades, com consentimento de Zeus (Id., vv. 75-80), sequestrou Perséfone. Deméter, ao saber que Hades havia sequestrado sua filha, afasta-se do Olimpo e perambula pela terra na figura de uma velha chegando a Elêusis.

Deméter decidiu não mais voltar ao Olimpo e vagou pela terra, na figura de uma velha, chegando a Elêusis Dor mais maligna e terrível o ânimo da deusa invadiu Tendo com o Cronida de sombrias nuvens se irritado, em seguida afastando-se da assembleia dos deuses e do alto Olimpo partiu para as cidades e os campos opulentos dos homens, dissimulando a aparência por muito tempo (HOMERO, s.d., vv. 90-94).

Ao adentrar no território de Elêusis, e ser recebida por Mentanira, a deusa se propõe a cuidar do seu filho mais novo, Demofonte (Id., vv. 100-105). Tendo a 
Religare, ISSN: 19826605, v.16, n.2, dezembro de 2019, p.714-734

intenção de fazer da criança um imortal, Deméter a ungia (Id., vv. 235-240) e colocava-a no fogo à noite. A criança crescia igual a um deus, não comendo pão, nem mamando. E carinhosamente o assoprava enquanto em seu colo o mantinha.

Mentanira descobre os planos de Deméter ao ver seu filho em meio às braças. Ao ser descoberta, Deméter revela seus planos à Mentanira, dizendo “Imortal e por todo o tempo agerato, o filho teu/ Eu tornaria, com um privilégio perene; Ora já é impossível que escape ao fado da morte" (Id., vv. 260-262). Neste contexto, Zeus solicita a Deméter que volte ao Olimpo e prossiga com seus afazeres, pois a terra que tudo nutre estava em um ano terrível. A deusa não permitiu (Id., vv. 330-335) que nenhuma semente brotasse da terra enquanto não estivesse com sua filha. Zeus, o senhor dos raios e deus dos deuses, envia Hermes ao encontro do seu irmão Hades, para que ele entregue Perséfone à sua mãe.

Sendo generoso, Hades permite que Perséfone retorne para os braços da sua mãe, mas, astuto, fez com que a filha de Deméter ingerisse sementes de Romã, símbolo de aliança, e ali Perséfone teria que passar um terço do ano. Notese a citação: "Sua filha consentiu passasse, do ciclo anual, A terça parte no seio da bruma tenebricosa, As outras duas, porém, com a mãe, entre os imortais" (Id., vv. 445-447). Ao rever sua filha, a deusa permite que os frutos da terra voltem a crescer, a fim de que a humanidade não perecesse.

\section{Considerações finais}

Diante do exposto, o objetivo deste artigo foi apresentar a literatura da teogonia hesiódica e dos escritos de autoria anônima Hino Homérico a Deméter. Foram apresentados alguns conceitos sobre o mito, sagrado, e religião, e sua importância no espaço geográfico e sócio-cosmológico no universo grego, bem como o lugar que têm algumas narrativas e ritos, na cultura dos povos antigos, na qualidade de elementos da manifestação de sua religiosidade. 
Religare, ISSN: 19826605, v.16, n.2, dezembro de 2019, p.714-734

Depreende-se que a representação do mito de Deméter, juntamente com seu sentido e natureza, alcança significação a partir da compreensão das suas origens, que se dá segundo Brandão, na chegada dos primeiros indo-europeus por volta século XIX a.C ao território da futura Hélade. Devendo reportar-se a um referencial teórico baseado em vestígios históricos da deusa entre os povos pré-helênicos e inseri-la no panteão grego, e, com base nestes vestígios, verificar o sagrado a partir da análise da linhagem genealógica de epítetos que lhe são atribuídos.

Para o esclarecimento dos fenômenos da natureza (ciclo anual de colheita), o mito apresentado pode ser utilizado como uma possível legitimação de uma colheita mal sucedida ou qualquer outro fenômeno que esteja atrelado à agricultura, ciclos anuais de colheita, casamento e fertilidade. O culto de Deméter e Perséfone, originada em Creta, por diversas vezes as duas divindades foram invocadas como (Duas Deusas) e atribuíam o nome a elas de Deméteres. Apresentou-se, aqui, uma leitura introdutória dos textos, servindo de base para aprofundamentos futuros dos estudos de antiguidade, a partir de uma abordagem historiográfica centrada na dimensão de pertinência histórica.

\section{Referências}

BRANDÃO, Junito de Souza. Mitologia grega. 18. ed. Petrópolis: Editora Vozes, 2004. I v.

BURKERT, Walter. A religião grega nas épocas arcaica e clássica. Lisboa: Fundação Calouste Gulbenkian, 1993.

CARTLEDGE, Paul (Org.). História ilustrada Grécia Antiga. 2. ed. São Paulo: Ediouro, 2009.

DA SILVA, Evandro César Cantaria. Resenha: O sagrado: um estudo do elemento não-racional na ideia do divino e a sua relação com o racional. São Bernardo do Campo: Imprensa Metodista, 1985. In: Theos: Revista Eletrônica de Reflexão Teológica, v. 1, p. 2, jul.-dez. 2005. Disponível em: <http://www.revistatheos.com.br/Artigos\%20Anteriores/Resenha_01_01.pdf.>. Acesso em: 10 jul. 2019.

DER LEEUW, Van. L'homme primitif et la religion. Paris, Alcan, 1940. 
Religare, ISSN: 19826605, v.16, n.2, dezembro de 2019, p.714-734

ELIADE, Mircea. História das crenças e das ideias religiosas. Tradução Roberto Cortes de Lacerda. Rio de Janeiro: Zahar Editores, 1978. 2 v. . História das crenças e das idéias religiosas. Chicago: Payot, 1989. O sagrado e o profano. São Paulo: Martins Fontes, 1992. - História das crenças e das ideias religiosas. Rio de Janeiro: Jorge Zahar Editor, 2010. $1 \mathrm{v}$.

FINLEY, M. Grécia primitiva: idade do bronze e idade arcaica. São Paulo: Martins Fontes, 1990.

HESÍODO. Teogonia. São Paulo: Iluminuras, 2012.

MASSI, Maria, Lúcia. Demeter: a repulsão medida. 2001. 133f. Dissertação (Mestrado em Letras) - Universidade Federal de São Paulo: Centro de Letras e Ciências humanas, 2001.

MORRIS, I. Use and abuse of Homer. In: CAIRNS, D. L. (Ed.). Oxford readings in Homer's Iliad. Oxford: Oxford University Press, 2001.

MOSSÉ, C. A Grécia arcaica de Homero a Ésquilo. Lisboa: Ed. 70, 1989.

OTTO, Rudolf. O sagrado. São Paulo: Vozes, 2007.

PAGE, D. O mundo homérico. In: LLOYD-JONES, H. (Org.). O mundo grego. Rio de Janeiro: Zahar, 1965, p. 13.

SERRA, Ordep. Hinos Homéricos a Deméter. Tradução, notas e comentário: Ordep Serra. 18. ed. São Paulo: Editora Odisseuss, 2009. p. 20. (Coleção Kouros).

VERNANT, Jean-Pierre. Mito e pensamento entre os gregos: estudos de psicologia histórica. São Paulo: DIFEL/EDUSP, 1973.

VERNANT, Jean-Pierre. Mito e religião na Grécia Antiga. São Paulo: Editora: Martins Fontes, 2009.

Recebido em 23-03-2019.

Aprovado em 08-08-2019. 